devem ser estabelecidos em nível central e estadual; a produção nacional de reagentes para diagnóstico, já estabelecida em pequena escala, deve ser estimulada, substituindo-se produtos importados de custo proibitivo; a produção nacional de vacina para hepatite B deve ser avaliada com vistas a seu preparo no país e uso nas áreas e populações mais atingidas; estudos sobre as hepatites virais em todos seus aspectos devem ser amplamente estimulados no país; uma conscientização para o problema deve ser atingida, como uma das medidas primárias para reduzir o impacto destas viroses, o qual somente se agravará ao longo do tempo, caso não adotemos posições definidas e atuantes.

$O$ recente lançamento do Programa de Hepatite Viral da Organização Mundial da Saúde nos indica claramente o caminho a seguir. state level. The production of diagnostic reagents, already established on a small scale, should be stimulated to avoid prohibitive imports costs. The national production of a vaccine for hepatitis $B$ should be evaluated with a view to using it in populations most affected. Studies on the types of viral hepatitis must be encouraged throughout the country. An awareness of the problem will help to reduce the impact of these viruses which can only augment if the right attitudes are not adopted by the community at large.

The recent launching of the Viral Hepatitis Programme of the World Health Organization indicates clearly the path we must follow in the future.

\author{
Hermann G. Schatzmayr \\ Departamento de Virologia da Fundação Oswaldo Cruz \\ Membro do Comitê de Assessoria Técnica do Programa \\ de Hepatite Viral da Organização Mundial da Saúde
}

\section{O FOCO BRASILEIRO DE ONCOCERCOSE}

Mais de uma década após o achado da oncocercose no Brasil 1345 - entre indios do grupo Yanomami, habitantes do extremo norte do País - é tempo agora de saber-se qual o significado real do foco descoberto e seu provável destino.

Algumas investigações preliminares 67891014 , bastante limitadas, feitas de 1974 a 1977 , revelaram que a endemia, embora extensa, não comprometia todo o grupo. A infecção era mais comum e mais acentuada nas aldeias ou malocas erguidas próximo à serra do Parima, sobretudo em torno de sua porção meridional 11 . Além disso, afora uns poucos missionários e raros membros de uma pequena tribo Makiritare (Mayongong), que viviam junto a indígenas dessa área, nenhuma outra pessoa estranha apareceu infectada na região ou circunvizinhança; a doença, aparentemente, estava restrita ao centro do território Yanomami.

Os indios Yanomami constituem um grupo primitivo e arredio, em grande parte, ainda hoje, isolado, graças à dificuldade de acesso aos locais onde se abrigam, dentro de uma zona montanhosa nos dois lados

\section{THE BRAZILIAN FOCUS OF ONCHOCERCIASIS}

It is more than a decade since the finding of onchocerciasis in Brazil 345 among Yanomami indians in the extreme north of the country - and the time is ripe to evaluate the significance of this finding.

Preliminary limited investigation undertaken between 1974 and 1977 showed that this endemic disease although extensive did not effect the whole study group 67891014 . The infection was more frequent in the indian settlements near the serra of Parima especially in its meridional portion ${ }^{11}$. Also, apart from a few missionaries and rare members of the Makiritare (Mayongong) tribe, who lived with the indians of the area no other person was infected in the region. Apparently the disease was restricted to the centre of Yanomami territory.

The Yanomami are a group of primitive indians isolated by the difficulty of access to the mountainous zone that they inhabit on the two sides of the frontier between Brazil and Venezuela. Their number is esti- 